\title{
Use of Bicarbonates to Inhibit in vitro Colony Growth of Botrytis cinerea
}

\author{
Cristi L. Palmer, Former Graduate Student, R. Kenneth Horst, Department of Plant Pathology, and Robert W. \\ Langhans, Department of Floriculture and Ornamental Horticulture, Cornell University, Ithaca, NY 14853
}

\begin{abstract}
Palmer, C. L., Horst, R. K., and Langhans, R. W. 1997. Use of bicarbonates to inhibit in vitro colony growth of Botrytis cinerea. Plant Dis. 81:1432-1438.

Fungicide resistance in Botrytis cinerea has caused increased concerns about losses due to gray mold on many important agricultural and horticultural crops. Since bicarbonates have been reported to be an effective control of powdery mildew on greenhouse roses, the purpose of this research was to determine the effectiveness of bicarbonates against B. cinerea. Assessments were made of in vitro fungal colony growth in response to ammonium, potassium, and sodium bicarbonates. Bicarbonates inhibited colony growth at concentrations as low as $20 \mathrm{mM}$. In addition, comparisons of several ammonium, potassium, and sodium salts were conducted to determine whether cation or anion is the active moiety. Although the bicarbonate anion primarily affected growth, the ammonium cation also contributed greatly to fungal growth inhibition. With the exception of dibasic phosphate, only salts with high $\mathrm{pK}_{\mathrm{a}}$ values or that are reducing agents, or both, decreased colony growth. The effect of $\mathrm{pH}$ on $B$. cinerea was then examined. Since bicarbonate anion concentration is related to $\mathrm{pH}$, this parameter was examined in combination with several salts to separate $\mathrm{pH}$ effects from bicarbonate effects. As $\mathrm{pH}$ increased from 7.0 to 8.5 , colony growth decreased with bicarbonates and phosphates, but not with ammonium sulfate. Since bicarbonates and phosphates decreased colony growth more than could be accounted for from $\mathrm{pH}$ alone, and since both have buffering characteristics, buffering capacity was examined and found to decrease colony growth but not as much as bicarbonate. Therefore, bicarbonates control $B$. cinerea colony growth in vitro, and both $\mathrm{pH}$ and buffering capacity contribute to, but are not solely responsible for, growth inhibition.
\end{abstract}

Botrytis cinerea Pers.:Fr., anamorph of Botryotinia fuckeliana (deBary) Whetzel and a member of the family Sclerotinaceae, causes gray mold on many important agricultural and horticultural crops, including begonia, geranium, grape, lettuce, rose, and tomato (9). Gray mold can be problematic during all phases of crop production, resulting in heavy losses. For example, in the early stages of growth, damping-off can affect seedling geraniums. $B$. cinerea also affects mature plants by colonizing weak tissues such as flower petals and leaves within the lower canopy as well as attacking compromised stems from mother plants during cutting production. Moreover, postharvest problems can occur during the storage of cut flowers and of fruit.

Incidence of gray mold can be reduced through manipulation of crop environment and through usage of traditional chemical fungicides. Control for $B$. cinerea can be obtained in greenhouses by raising temperatures and by venting to lower humidity. However, many crops are grown in situations where environmental controls

Corresponding author: R. K. Horst

E-mail: rkh1@cornell.edu

Accepted for publication 24 August 1997.

Publication no. D-1997-1014-01R

(C) 1997 The American Phytopathological Society are limited or nonexistent. Traditional chemical fungicides have had measurable success, but $B$. cinerea has developed resistance to common fungicides used to control gray mold. For example, benomyl resistance has been documented in the United States and in Israel $(8,16)$. Since pesticide registration is a costly and lengthy process and many fungicides may be withdrawn from the turf and ornamental markets due to the Food Quality Protection Act, alternative means of safe control must be developed. Neem oil, horticultural oils, sulfur dioxide, silicates, phosphonates, phosphates, and bicarbonates have exhibited potential for disease control in other disease systems $(1-5,12,18,26,28)$. Bicarbonates are generally regarded as safe by the Environmental Protection Agency and therefore will cause fewer problems with registration.

Bicarbonates have been demonstrated to effectively control a wide range of fungi, including food spoilage organisms and plant pathogens. Sodium bicarbonate reduces slightly the CFU of Aspergillus parasiticus, Fusarium graminearum, and Penicillium griseofulvum obtained from treated cracked-corn kernels, whereas ammonium bicarbonate greatly reduces CFUs of those same food spoilage fungi (15). Bicarbonates have been demonstrated to control powdery mildew diseases of cucumber (11), euonymus (30), and rose (12). Ziv and Zitter (31) found pronounced detrimental effects of bicarbonates on disease incidence and in vitro growth of several cucurbit foliar pathogens: Alternaria $\mathrm{cu}$ cumerina, Colletotrichum orbiculare, Didymella bryoniae, and Ulocladium cucurbitae. Bicarbonates and carbonate salts amended to water agar inhibit Sclerotium rolfsii sclerotial germination (24). In an initial report, Ziv and Hagiladi (30) claim bicarbonates control B. cinerea, but no host was mentioned; however, Ricker and Punja (27) tested B. cinerea on V8 agar containing 10 and $100 \mathrm{mM} \mathrm{NaHCO}_{3}$ and found 28 and $100 \%$ inhibition, respectively.

This study was initiated to further elucidate the potential for bicarbonates to control B. cinerea. Research objectives to achieve this goal include (i) a determination of efficacies of bicarbonates against $B$. cinerea in vitro colony growth; (ii) an examination of cations and anions of various salts for active moieties; and (iii) an examination of the roles $\mathrm{pH}$ and buffering capacity play in bicarbonate activity. Preliminary results of this work have been presented (20-22).

\section{MATERIALS AND METHODS}

$B$. cinerea isolated from geranium (Pelargonium $\times$ hortorum L.H. Bailey) was used to evaluate bicarbonate inhibition of in vitro colony growth. Potato dextrose agar (PDA) at $39.0 \mathrm{~g} /$ liter was autoclaved for $17 \mathrm{~min}$ and then incubated at $55^{\circ} \mathrm{C}$ until it was poured into sterile plastic petri plates. Prior to cooling and solidification, supplements to PDA were added and, for appropriate experiments, $\mathrm{pH}$ was adjusted with $\mathrm{HCl}$ and $\mathrm{NaOH}$ or $\mathrm{KOH}$. B. cinerea conidia were transferred to solidified plates with a heat-sterilized glass rod; plates were then sealed with Parafilm. Five plates per treatment were inoculated and then incubated at room temperature with natural cycles of light and dark. Colony diameters at the widest point were measured at $144 \mathrm{~h}$. Colonies that grew appeared opaque within $48 \mathrm{~h}$; colonies that did not grow had clear spore residues at $144 \mathrm{~h}$. Spore residues were included in diameter measurements even if no colony formation occurred. $B$. cinerea cultures for inoculation were maintained on unsupplemented PDA.

Ammonium, potassium, and sodium bicarbonate (Church and Dwight Co., Inc., Princeton, NJ) concentrations from 0 to $100 \mathrm{mM}$ were examined. To determine whether bicarbonates have fungistatic or fungitoxic effects on $B$. cinerea, plugs from treatments with no growth were transferred to unsupplemented PDA; colony diameters were measured $172 \mathrm{~h}$ later. 
To determine possible active moieties, the following salts were amended to PDA at 25 and $50 \mathrm{mM}$ with no adjustment to pH: $\mathrm{NaHCO}_{3}, \mathrm{NaCl}, \mathrm{NaF}, \mathrm{NaOH}, \mathrm{NaNO}_{2}$, $\mathrm{NaH}_{2} \mathrm{PO}_{4}, \quad \mathrm{Na}_{2} \mathrm{HPO}_{4}, \quad \mathrm{Na}_{2} \mathrm{SO}_{4}, \quad \mathrm{Na}_{2} \mathrm{SO}_{3}$, $\mathrm{Na}_{2} \mathrm{~S}_{2} \mathrm{O}_{3}$, and $\mathrm{Na}_{2} \mathrm{~S}_{2} \mathrm{O}_{5}, \mathrm{KHCO}_{3}, \mathrm{~K}_{2} \mathrm{CO}_{3}$, $\mathrm{KCl}, \mathrm{KOH}, \mathrm{KNO}_{3}, \mathrm{KH}_{2} \mathrm{PO}_{4}, \mathrm{~K}_{2} \mathrm{HPO}_{4}$, $\mathrm{K}_{3} \mathrm{PO}_{4}, \quad \mathrm{NH}_{4} \mathrm{HCO}_{3}, \quad\left(\mathrm{NH}_{4}\right)_{2} \mathrm{CO}_{3}, \mathrm{NH}_{4} \mathrm{Cl}$, $\mathrm{NH}_{4} \mathrm{NO}_{3}$, and $\left(\mathrm{NH}_{4}\right)_{2} \mathrm{SO}_{4}$.

Several experiments were conducted to determine effects of $\mathrm{pH}$ and buffering capacity on $B$. cinerea colony growth. The effect of $\mathrm{pH}$ on colony growth was examined on adjusted PDA at $\mathrm{pH}$ 5.0, 6.0, 7.0, 8.0, 9.0, and 10.0. In addition, media supplemented with $25 \mathrm{mM}$ and $50 \mathrm{mM}$ $\mathrm{NH}_{4} \mathrm{HCO}_{3}$ or $\mathrm{NaHCO}_{3}$ were evaluated at $\mathrm{pH} 4.5,5.0,5.5,6.0,6.5,7.0,7.5,8.0$, and 8.5. Monobasic and dibasic sodium phosphates at $50 \mathrm{mM}$ were added to PDA, and $\mathrm{pH}$ was adjusted to 7.0, 7.5, 8.0, and 8.5. Media supplemented with $10 \mathrm{mM}$ $\left(\mathrm{NH}_{4}\right)_{2} \mathrm{SO}_{4}$ or $20 \mathrm{mM} \mathrm{NH} \mathrm{HCO}_{3}$, and unsupplemented PDA were tested at $\mathrm{pH}$ 7.0, 7.5, 8.0, and 8.5. To determine whether buffering capacity contributes to bicarbonate efficacy, $\mathrm{N}$-[2-acetamido]-2-aminoethene sulfonic acid (ACES) buffer (Sigma, St. Louis, $\mathrm{MO}$ ), $\mathrm{pK}_{\mathrm{a}} 6.8$, and $\mathrm{KHCO}_{3}$ were compared at $50 \mathrm{mM}$.

Data were analyzed using statistical program SuperANOVA (Abacus Concepts, Inc., Berkeley, CA). Analyses performed included one-way and two-way ANOVA to determine significance of treatments in altering colony growth and Duncan new multiple range using $\alpha=0.05$ to determine differences among treatments.

\section{RESULTS}

Bicarbonate concentration. Bicarbonates decreased $B$. cinerea colony growth as bicarbonate concentration increased (Fig. 1). Optimal concentrations for complete inhibition of $B$. cinerea varied depending upon which cation associated with the bicarbonate was incorporated into PDA. No colony expansion was measurable with $\mathrm{NaHCO}_{3}$ at $50 \mathrm{mM}$, while the molarity for complete radial growth inhibition with $\mathrm{KHCO}_{3}$ was slightly higher, $60 \mathrm{mM}$. Ammonium bicarbonate inhibited colony formation at a lower concentration, $20 \mathrm{mM}$. In addition to inhibiting $B$. cinerea colony growth, $\mathrm{NH}_{4} \mathrm{HCO}_{3}$ was also fungitoxic (Table 1). Even at $10 \mathrm{mM}$, no growth was observed $172 \mathrm{~h}$ after colonies were transferred. Fungistatic versus fungitoxic activity was not determined with $\mathrm{KHCO}_{3}$, because some colony growth occurred with salt concentrations up to $150 \mathrm{mM}$ (data not shown).

Salt studies. Salts differed dramatically from no alteration to moderate reduction to complete inhibition of $B$. cinerea colony growth (Table 2). Bicarbonate, carbonate, hydroxide, dibasic and tribasic phosphate, fluoride, nitrite, sulfite, and metabisulfite significantly decreased $(P<0.0001)$ colony growth; whereas chloride, monobasic phosphate, nitrate, and sulfate salts had no discernible activity on colony diameters. Except for $\mathrm{NH}_{4} \mathrm{HCO}_{3}$, cations did not significantly alter anion activity. All inhibiting salts except sodium metabisulfite and sodium fluoride have $\mathrm{pK}_{\mathrm{a}}$ values greater than 7.8. In addition to being alkaline, sodium sulfite and sodium nitrite are reducing agents, as is the acidic sodium metabisulfite.

pH studies. Growth of $B$. cinerea varied with $\mathrm{pH}$; as $\mathrm{pH}$ increased from 6.5 to 10.0 , $B$. cinerea colony growth decreased (Fig. $2)$. No differences were seen in colony growth from $\mathrm{pH} 5.0$ to $\mathrm{pH} 6.0$. B. cinerea can grow on PDA at $\mathrm{pH} 9.0$, albeit at a reduced rate, but at $\mathrm{pH} 10.0$, no growth occurred. Effects of bicarbonate concentration and $\mathrm{pH}$ on $B$. cinerea colony growth were assessed on PDA supplemented with $\mathrm{NH}_{4} \mathrm{HCO}_{3}$ at $0,5,10$, and $20 \mathrm{mM}$. From $\mathrm{pH} 6.5$ to $\mathrm{pH} 8.5$, as bicarbonate concentration and $\mathrm{pH}$ increased, $B$. cinerea colony growth decreased $(P<0.0001)$. No colonies were formed at 10 and $20 \mathrm{mM}$ $\mathrm{NH}_{4} \mathrm{HCO}_{3}$ above pH 7.5 (Fig. 3). Below
$\mathrm{pH} 6.5$, no significant differences in growth occurred among bicarbonate concentrations. Similar results were obtained with $\mathrm{NaHCO}_{3}$. When grown on PDA containing four concentrations of $\mathrm{NaHCO}_{3}(0,5,25$, and 50 $\mathrm{mM}), B$. cinerea grew significantly less on bicarbonate-supplemented PDA than on unsupplemented PDA at $\mathrm{pH} 6.5$ and greater $(P<0.0001)$ (Fig. 4). Generally, increased inhibition was seen with increasing bicarbonate concentration and with increasing $\mathrm{pH}$. No growth occurred with $50 \mathrm{mM} \mathrm{Na}$ $\mathrm{HCO}_{3}$ above $\mathrm{pH}$ 7.5. Below pH 6.5, no significant differences were observed among the four treatments.

Dibasic phosphates reduced growth of B. cinerea from $\mathrm{pH} 7.0$ through $\mathrm{pH} 8.5(P$ $<0.0001)$ in comparison to $\mathrm{pH}$ controls (data not shown); no growth occurred with either phosphate above 8.0. Monobasic and dibasic sodium phosphate differed only at $\mathrm{pH} 7.0$, which may be due to anomalous readings for dibasic sodium phosphate, since concentrations of monobasic and dibasic phosphate depend directly on solution $\mathrm{pH}$.

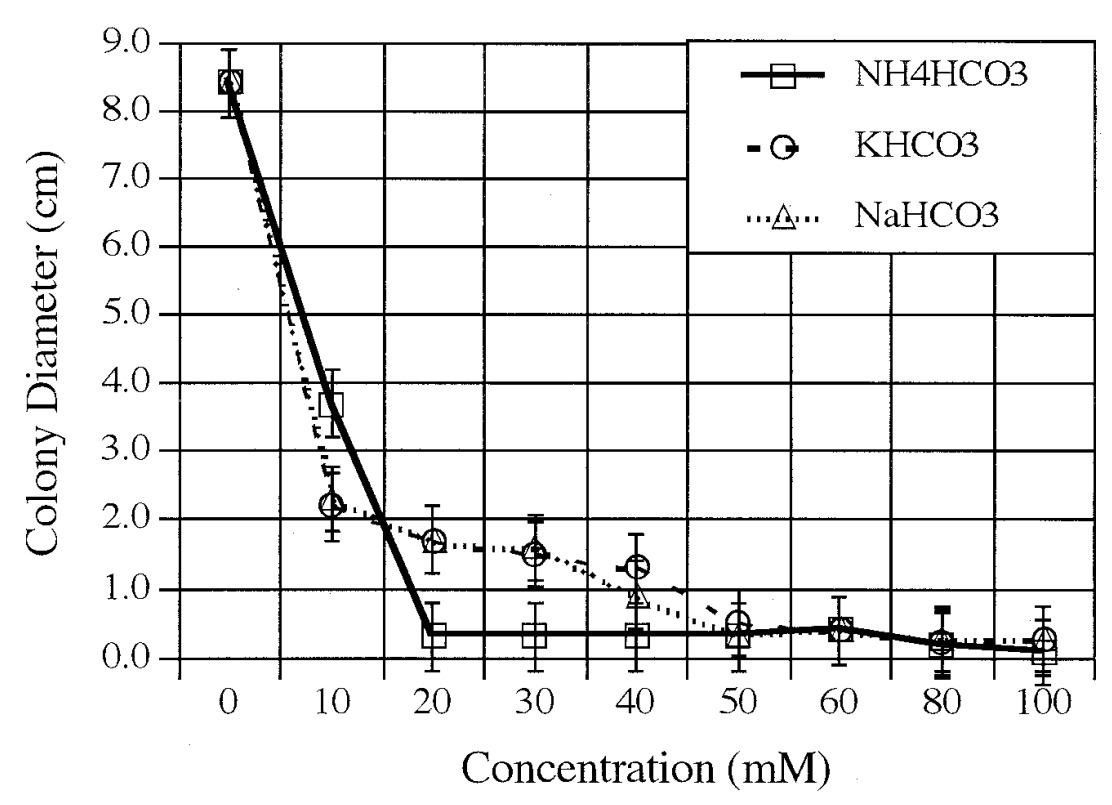

Fig. 1. Effects of bicarbonate concentration on in vitro colony diameters of Botrytis cinerea on potato dextrose agar at $144 \mathrm{~h}$. Media $\mathrm{pH}$ was not adjusted after amending with bicarbonate. Spore residues from inoculation were included in measurements. Bars represent critical difference at $\alpha=0.05$.

Table 1. Diameters in cm of Botrytis cinerea colonies $144 \mathrm{~h}$ after placement onto potato dextrose agar (PDA) amended with $\mathrm{NH}_{4} \mathrm{HCO}_{3}$ at increasing concentrations up to $50 \mathrm{mM}$

\begin{tabular}{ccc}
\hline $\mathbf{N H}_{\mathbf{4}} \mathbf{H C O} \mathbf{3}_{\mathbf{3}}$ concentration & $\begin{array}{c}\text { Mean colony diameter } \\
\text { at } \mathbf{1 4 4} \mathbf{~ h}(\mathbf{c m})^{\mathbf{y}}\end{array}$ & $\begin{array}{c}\text { Mean colony diameter } \\
\text { at } \mathbf{1 7 2} \mathbf{~ h} \text { after transfer }(\mathbf{c m})^{\mathbf{z}}\end{array}$ \\
\hline $0 \mathrm{mM}$ & $8.36 \mathrm{a}$ & $\ldots$ \\
$5 \mathrm{mM}$ & $2.18 \mathrm{~b}$ & $\ldots$ \\
$10 \mathrm{mM}$ & $0.40 \mathrm{c}$ & $0.0 \mathrm{c}$ \\
$20 \mathrm{mM}$ & $0.38 \mathrm{c}$ & $0.0 \mathrm{c}$ \\
$30 \mathrm{mM}$ & $0.36 \mathrm{c}$ & $0.0 \mathrm{c}$ \\
$40 \mathrm{mM}$ & $0.34 \mathrm{c}$ & $0.0 \mathrm{c}$ \\
$50 \mathrm{mM}$ & $0.34 \mathrm{c}$ & $0.0 \mathrm{c}$ \\
\hline
\end{tabular}

${ }^{y}$ Values followed by the same letters are not significantly different at $\alpha=0.05$.

${ }^{z}$ Treatments exhibiting no colony formation were transferred to unsupplemented PDA, and subsequent growth from plugs was measured at $172 \mathrm{~h}$. 
Effects of ammonium sulfate and ammonium bicarbonate on $B$. cinerea colony growth were compared from $\mathrm{pH} 7.0$ to $\mathrm{pH}$ 8.5 at equal molarities for $\mathrm{NH}_{4+}$. While $\left(\mathrm{NH}_{4}\right)_{2} \mathrm{SO}_{4}$ significantly decreased growth $(P=0.012), \mathrm{NH}_{4} \mathrm{HCO}_{3}$ completely inhibited growth $(P<0.0001)$ (Table 3$)$. Ammonium sulfate above $\mathrm{pH} 8.0$ slightly re- duced colony growth in comparison to unsupplemented controls.

To determine whether buffering capacity reduces $B$. cinerea colony growth, $50 \mathrm{mM}$ $\mathrm{KHCO}_{3}$ and $50 \mathrm{mM}$ ACES buffer were amended to PDA, and the $\mathrm{pH}$ was adjusted to $6.5,7.0,7.5,8.0$, and 8.5. The ACES buffer and $\mathrm{KHCO}_{3}$ exhibited similar ef-

Table 2. Diameter in cm of Botrytis cinerea colonies $144 \mathrm{~h}$ after placement onto potato dextrose agar amended with various salts

\begin{tabular}{|c|c|c|c|c|}
\hline Salt & $\begin{array}{l}\text { Chemical } \\
\text { formula }\end{array}$ & $\mathbf{p K}_{\mathrm{a}}$ & $\begin{array}{l}\text { Colony diameter } \\
\text { at } 25 \mathrm{mM}(\mathrm{cm})\end{array}$ & $\begin{array}{l}\text { Colony diameter } \\
\text { at } 50 \mathrm{mM}(\mathrm{cm})\end{array}$ \\
\hline Ammonium bicarbonate & $\mathrm{NH}_{4} \mathrm{HCO}_{3}$ & 7.8 & 0.28 & 0.23 \\
\hline Ammonium carbonate & $\left(\mathrm{NH}_{4}\right)_{2} \mathrm{CO}_{3}$ & $\ldots$ & 0.28 & 0.28 \\
\hline Ammonium chloride & $\mathrm{NH}_{4} \mathrm{Cl}$ & $5.0-5.1$ & 7.42 & 7.02 \\
\hline Ammonium nitrate & $\mathrm{NH}_{4} \mathrm{NO}_{3}$ & 5.4 & 8.40 & 8.38 \\
\hline Ammonium sulfate & $\left(\mathrm{NH}_{4}\right)_{2} \mathrm{SO}_{4}$ & 5.5 & 8.40 & 8.18 \\
\hline Potassium bicarbonate & $\mathrm{KHCO}_{3}$ & 8.2 & 1.54 & 1.01 \\
\hline Potassium carbonate & $\mathrm{K}_{2} \mathrm{CO}_{3}$ & 11.6 & 0.30 & 0.30 \\
\hline Potassium chloride & $\mathrm{KCl}$ & 7.0 & 7.98 & 8.00 \\
\hline Potassium hydroxide & $\mathrm{KOH}$ & 13.5 & 0.58 & 0.32 \\
\hline Potassium nitrate & $\mathrm{KNO}_{3}$ & 7.0 & 7.80 & 7.82 \\
\hline $\begin{array}{l}\text { Potassium phosphate, } \\
\text { dibasic }\end{array}$ & $\mathrm{K}_{2} \mathrm{HPO}_{4}$ & Alkaline & 2.64 & 2.00 \\
\hline $\begin{array}{l}\text { Potassium phosphate, } \\
\text { monobasic }\end{array}$ & $\mathrm{KH}_{2} \mathrm{PO}_{4}$ & $4.4-4.7$ & 8.40 & 8.30 \\
\hline $\begin{array}{l}\text { Potassium phosphate, } \\
\text { tribasic }\end{array}$ & $\mathrm{K}_{3} \mathrm{PO}_{4}$ & Alkaline & 0.22 & 0.32 \\
\hline Potassium sulfate & $\mathrm{K}_{2} \mathrm{SO}_{4}$ & 7.0 & 8.40 & 8.40 \\
\hline Sodium bicarbonate & $\mathrm{NaHCO}_{3}$ & 8.3 & 1.35 & 0.38 \\
\hline Sodium carbonate & $\mathrm{Na}_{2} \mathrm{CO}_{3}$ & 11.6 & 0.30 & 0.28 \\
\hline Sodium chloride & $\mathrm{NaCl}$ & $6.7-7.3$ & 8.38 & 8.40 \\
\hline Sodium fluoride & $\mathrm{NaF}$ & 7.4 & 2.90 & 0.50 \\
\hline Sodium hydroxide & $\mathrm{NaOH}$ & $12.0-14.0$ & 0.40 & 0.40 \\
\hline Sodium metabisulfite & $\mathrm{Na}_{2} \mathrm{~S}_{2} \mathrm{O}_{5}$ & Acidic & 0.22 & 0.20 \\
\hline Sodium nitrite & $\mathrm{Na}_{2} \mathrm{NO}_{2}$ & 9.0 & 4.28 & 0.28 \\
\hline Sodium phosphate, dibasic & $\mathrm{Na}_{2} \mathrm{HPO}_{4}$ & 9.1 & 1.84 & 1.02 \\
\hline $\begin{array}{l}\text { Sodium phosphate, } \\
\text { monobasic }\end{array}$ & $\mathrm{NaH}_{2} \mathrm{PO}_{4}$ & 4.5 & 8.40 & 8.12 \\
\hline Sodium sulfate & $\mathrm{Na}_{2} \mathrm{SO}_{4}$ & $6.0-7.5$ & 7.86 & 8.26 \\
\hline Sodium sulfite & $\mathrm{Na}_{2} \mathrm{SO}_{3}$ & 9.0 & 5.88 & 2.16 \\
\hline Sodium thiosulfate & $\mathrm{Na}_{2} \mathrm{~S}_{2} \mathrm{O}_{3}$ & $6.5-8.0$ & 7.00 & 8.22 \\
\hline No salt & $\ldots$ & $\ldots$ & 8.25 & 8.25 \\
\hline $\operatorname{LSD} \alpha=0.05$ & & & 0.75 & 0.75 \\
\hline
\end{tabular}

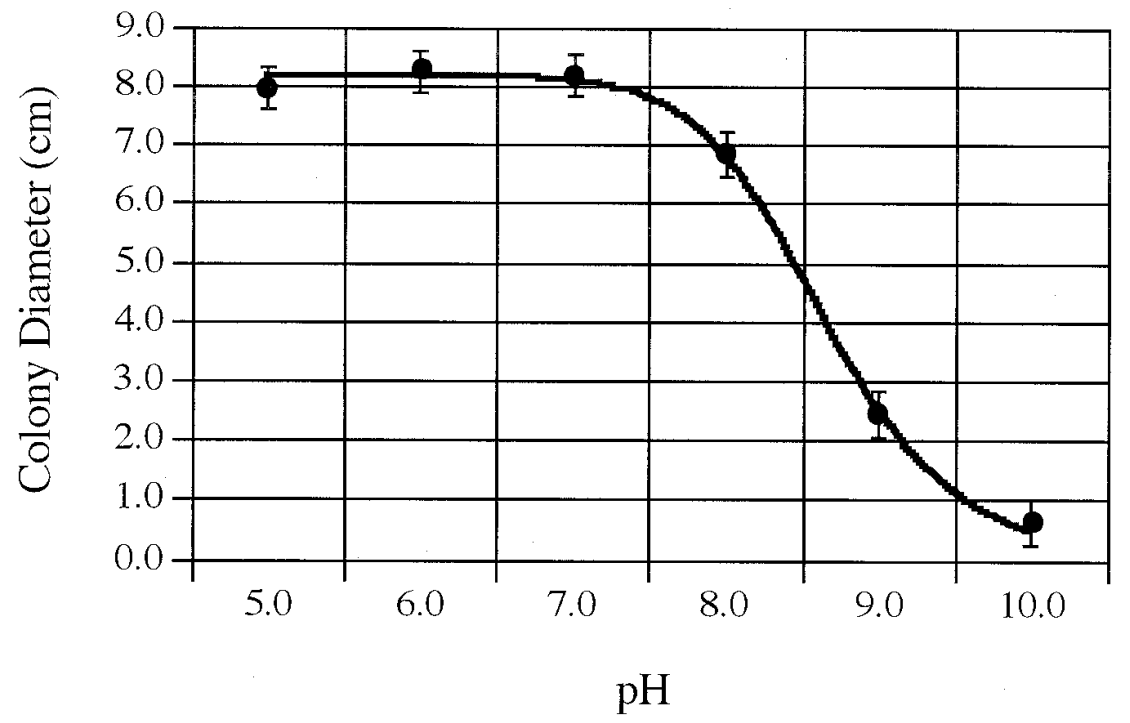

Fig. 2. Effects of $\mathrm{pH}$ on in vitro colony growth of Botrytis cinerea on potato dextrose agar at $144 \mathrm{~h}$. Media were adjusted with $\mathrm{HCl}$ and $\mathrm{KOH}$ or $\mathrm{NaOH}$. Spore residues from inoculation were included in measurements. Bars represent critical difference at $\alpha=0.05$.

fects on $B$. cinerea: as $\mathrm{pH}$ increased, colony diameters decreased (Fig. 5). However, with the exception of $\mathrm{pH} 8.5$, the decrease with ACES was not as great as with $\mathrm{KHCO}_{3}$.

\section{DISCUSSION}

Bicarbonate concentration. Ammonium, potassium, and sodium bicarbonates inhibit $B$. cinerea in vitro colony growth. $B$. cinerea has differential sensitivity to these bicarbonates, as demonstrated by its varying rates for complete inhibition of colony growth. Potassium and sodium bicarbonate have similar effects in reducing radial growth, but some abnormal growth can occur with $\mathrm{KHCO}_{3}$ at the highest concentration tested. $B$. cinerea is most sensitive to $\mathrm{NH}_{4} \mathrm{HCO}_{3}$. Different growth rates may be related to the ability of $B$. cinerea to compensate for elevated concentrations of the cations. The potassium cation is a critical component to maintain membrane integrity, but sodium is not utilized by cells as readily as potassium; this difference in metabolic usage explains the reason for $B$. cinerea to be slightly more tolerant of $\mathrm{KHCO}_{3}$. The ammonium cation can readily gain an electron to become ammonia gas, which by itself can prevent growth, providing $\mathrm{NH}_{4} \mathrm{HCO}_{3}$ two active moieties instead of one.

Concentrations for control of gray mold in field situations may be similar to concentrations needed for complete inhibition of $B$. cinerea radial colony growth. Several other pathogens have been demonstrated to be inhibited by bicarbonate both in vitro and in vivo. At $50 \mathrm{mM}, \mathrm{NH}_{4} \mathrm{HCO}_{3}$ prevented sclerotial germination of $S$. rolfsii (24) as well as significantly reducing the percentage of dead carrot plants from root rot (25). At $100 \mathrm{mM}, \mathrm{NaHCO}_{3}$ completely inhibited Rhizoctonia carotae growth on V8 agar and reduced the number of unacceptable carrots (27). In addition, ammonium, potassium, and sodium bicarbonate reduced Alternaria cucumerina colony growth on water agar and the number of lesions formed on cucumber leaves (31). Thus, similar concentrations of bicarbonates modify disease incidence and in vitro fungal development in several disease systems. Since foliar sprays will dry on plant surfaces, increasing bicarbonate concentrations, lower initial concentrations may be sufficient to control gray mold development provided adequate coverage is achieved.

Salt studies. Because chloride, nitrate, and sulfate salts had no activity against $B$. cinerea, the bicarbonate anion appears to be the active portion. Punja and Grogan (24) found that chloride, sulfate, nitrate, and monobasic phosphate had no activity on Sclerotium rolfsii, also a member of the Sclerotinaceae family. Cations may have some minor effects, as demonstrated by differential sensitivities to various bicarbonate salts. 
Since many common buffers include phosphate, it was unexpected that dibasic and tribasic phosphates would decrease colony diameters at rates similar to bicarbonates. However, Punja and Grogan (24) found similar results, in that carbonates and bicarbonates at $50 \mathrm{mM}$ completely inhibited germination of sclerotia, while dibasic phosphates greatly reduced germination. Moreover, phosphates have been implicated in rose powdery mildew control as well as inducing resistance, as demonstrated by reduced infections even 23 days after spray (26). Mucharromah and Kuc (17) demonstrated that phosphates induce systemic resistance in cucumber for diseases caused by bacteria, fungi, and viruses.

Bicarbonates and chlorides were tested at the same concentrations; hence osmotic effects within these colony growth studies were negligible. However, in field situations where bicarbonate solutions will become more concentrated due to evaporation, osmotic effects may play a role in disease reduction.

pH studies. Many salts with basic $\mathrm{pK}_{\mathrm{a}}$ values inhibited colony growth, indicating that $\mathrm{pH}$ may be a reason for the detrimental activity of bicarbonates. Most fungi, including $B$. cinerea, grow better in acidic to neutral conditions than in alkaline environments. For example, $S$. rolfsii sclerotial germination is inhibited above $\mathrm{pH} 7.0$ (24). Also, Webb (29) demonstrated that several fungi, including $B$. cinerea, germinate primarily in acidic conditions. However, $B$. cinerea can grow at reduced rates on media with high $\mathrm{pH}$. Bicarbonates reduce growth beyond that of merely elevated $\mathrm{pH}$; this inhibition is mediated by but not solely due to $\mathrm{pH}$. Curran and Montville (6) compared apple juice with bicarbonates and juice adjusted to $\mathrm{pH}$ similar to that amended with bicarbonate and observed that Hansenula wingei and Saccharomyces cerevisiae growth were reduced at elevated $\mathrm{pH}$ but not to the same extent as with bicarbonates. Homma et al. (10) conducted similar studies with $\mathrm{pH}$ on Penicillium citri, also concluding that another mechanism is involved.

The bicarbonate concentration in solution is directly related to the $\mathrm{pH}$ of that solution (Fig. 6A). Bicarbonates are ineffective under acidic conditions because carbonic acid predominates in solutions below $\mathrm{pH}$ 6.5. $\mathrm{H}_{2} \mathrm{CO}_{3}$ is unstable and decomposes into carbon dioxide and water. As $\mathrm{pH}$ increases to $\mathrm{pH} 8.5$, the concentration of bicarbonate increases. Above $\mathrm{pH}$ 8.5 , bicarbonate concentration decreases and the level of carbonate rises.

Ammonium bicarbonate has two active components: the ammonium cation, which can convert to ammonia gas, and the bicarbonate anion. At low pH, ammonium bicarbonate becomes ammonium, water, and carbon dioxide: $\mathrm{pH}<7.0, \mathrm{NH}_{4} \mathrm{HCO}_{3}+\mathrm{H}^{+}=$ $\mathrm{NH}_{4}^{+}+\mathrm{H}_{2} \mathrm{O}+\mathrm{CO}_{2}$. Since at low $\mathrm{pH}$, no inhibition was observed, it is highly unlikely that the ammonium ion contributes to decreased growth. At high $\mathrm{pH}$, ammonium bicarbonate degrades to ammonia gas, water, and bicarbonate: $\mathrm{pH}>7.0$, $\mathrm{NH}_{4} \mathrm{HCO}_{3}+\mathrm{OH}^{1-}=\mathrm{NH}_{3}+\mathrm{H}_{2} \mathrm{O}+\mathrm{HCO}_{3}{ }^{1-}$. Release of ammonia at high $\mathrm{pH}$ provides an additional active component. Ammo- nium bicarbonate passively diffuses into fungal cells (13).

The phosphate anion exhibits similar ionic changes through $\mathrm{pH}$. Below $\mathrm{pH} 2$, phosphoric acid is dominant in solution (Fig 6B). As pH increases, phosphoric acid gives way to monobasic phosphate and then to dibasic phosphate. Above $\mathrm{pH} 12.5$,

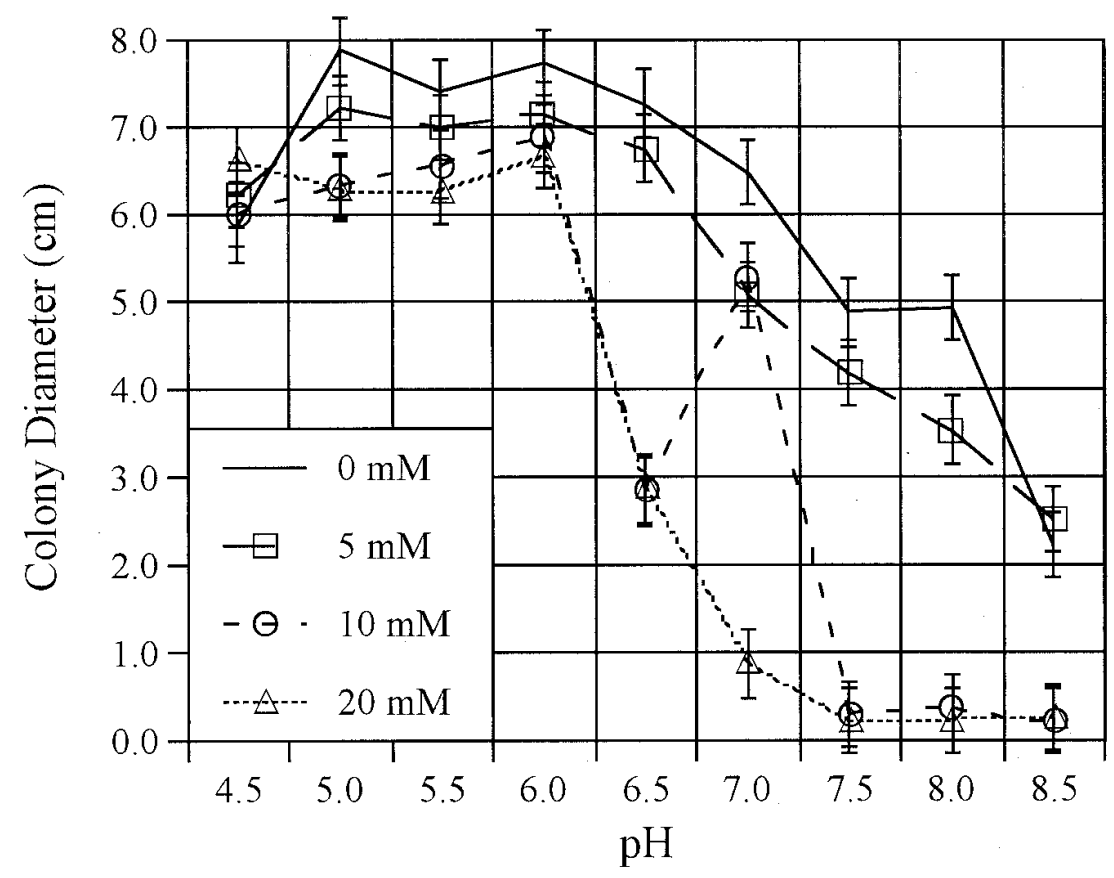

Fig. 3. Effects of $\mathrm{pH}$ and $\mathrm{NH}_{4} \mathrm{HCO}_{3}$ concentration on in vitro colony growth of Botrytis cinerea on potato dextrose agar at $144 \mathrm{~h}$. After amending with bicarbonate, media were adjusted with $\mathrm{HCl}$ and $\mathrm{KOH}$ or $\mathrm{NaOH}$. Spore residues from inoculation were included in measurements. Bars represent critical difference at $\alpha=0.05$.

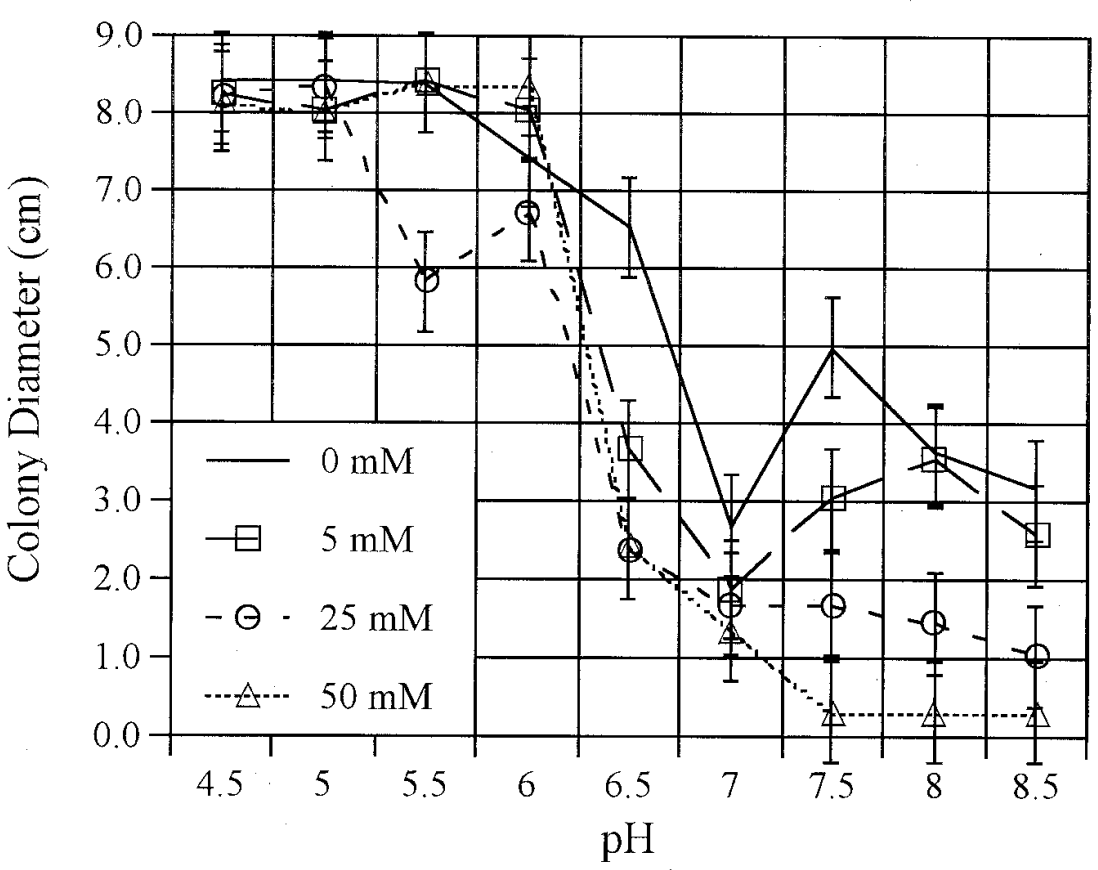

Fig. 4. Effects of $\mathrm{pH}$ and $\mathrm{NaHCO}_{3}$ concentration on in vitro colony growth of Botrytis cinerea on potato dextrose agar at $144 \mathrm{~h}$. After amending with bicarbonate, media were adjusted with $\mathrm{HCl}$ and $\mathrm{KOH}$ or $\mathrm{NaOH}$. Bars represent critical difference at $\alpha=0.05$. 
Table 3. Comparisons of colony diameters of Botrytis cinerea $144 \mathrm{~h}$ after placement onto potato dextrose agar amended with ammonium bicarbonate or ammonium sulfate

\begin{tabular}{|c|c|c|c|}
\hline pH & $\begin{array}{l}\text { Colony diameter } \\
\text { with } 0 \mathrm{mM}(\mathrm{cm})^{\mathrm{z}}\end{array}$ & $\begin{array}{l}\text { Colony diameter with } \\
10 \mathrm{mM}\left(\mathrm{NH}_{4}\right)_{2} \mathrm{SO}_{4}(\mathrm{~cm})\end{array}$ & $\begin{array}{c}\text { Colony diameter with } \\
20 \mathrm{mM} \mathrm{NH} \mathrm{HCO}_{3}(\mathrm{~cm})\end{array}$ \\
\hline 7.0 & $2.60 \mathrm{~b}$ & $4.42 \mathrm{e}$ & $0.28 \mathrm{a}$ \\
\hline 7.5 & $5.10 \mathrm{~g}$ & $4.74 \mathrm{f}$ & $0.24 \mathrm{a}$ \\
\hline 8.0 & $4.48 \mathrm{e}$ & $2.92 \mathrm{c}$ & $0.30 \mathrm{a}$ \\
\hline 8.5 & $3.70 \mathrm{~d}$ & $2.60 \mathrm{~b}$ & $0.22 \mathrm{a}$ \\
\hline
\end{tabular}

y Salt molarities were chosen to have equal concentrations of $\mathrm{NH}_{4}{ }^{+}$in solution.

$\mathrm{z}$ Values followed by the same letters are not significantly different at $\alpha=0.05$.

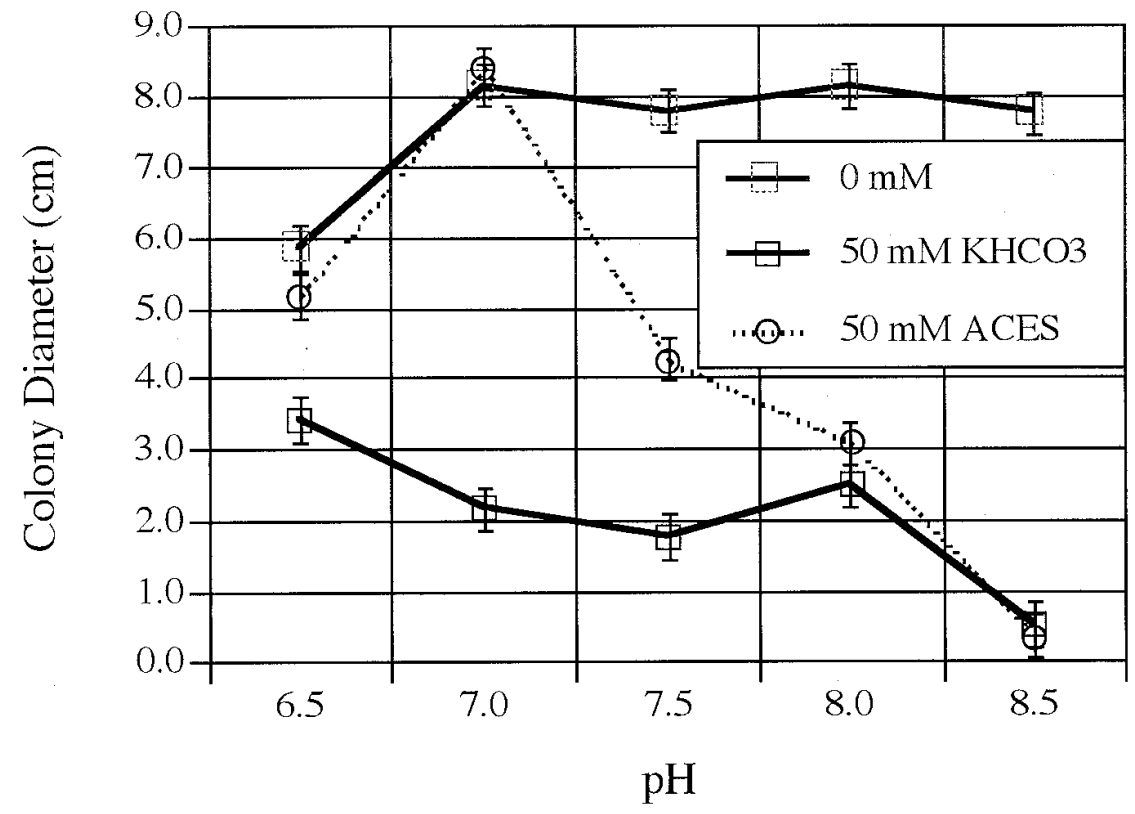

Fig 5. Effects of $\mathrm{KHCO}_{3}$ and ACES buffer through $\mathrm{pH}$ on in vitro colony growth of Botrytis cinerea on potato dextrose agar at $144 \mathrm{~h}$. After amending with bicarbonate or ACES, media were adjusted with $\mathrm{HCl}$ and $\mathrm{KOH}$ or $\mathrm{NaOH}$. Bars represent critical difference at $\alpha=0.05$.

tribasic phosphate predominates. Since dibasic phosphate has a similar structure to bicarbonate, the potential exists for interactions with fungal membranes.

Examination of the ammonium bicarbonate and sulfate data indicates that DePasquale and Montville's (7) theory regarding the primary mode of action for ammonium bicarbonate cannot generally be applied to fungi. Unlike Botrytis, Fusarium readily grows in alkaline conditions without any significant reduction in colony growth and will germinate readily (29). In studies by DePasquale and Montville, release of ammonia gas from ammonium sulfate at high $\mathrm{pH}(\mathrm{pH}>8.3)$ gave inhibition equivalent to that previously seen by ammonium bicarbonate for Fusarium and Penicillium. Since ammonium has very little negative impact on $B$. cinerea colony growth, while ammonia does, their conclusion that ammonia release in high $\mathrm{pH}$ solutions inhibits fungi is valid. Sulfate is a polyprotic salt similar to bicarbonate and phosphate. However, the first dissociation constant is very high, and all $\mathrm{H}_{2} \mathrm{SO}_{4}$ completely dissociates into $\mathrm{H}^{+}$ and $\mathrm{HSO}_{4}^{-}$(Fig. 6C). Above pH 4.25, sulfate is completely dissociated into $\mathrm{SO}_{4}{ }^{-2}$ and its associated cations. Therefore, ammonia gas release would occur at any $\mathrm{pH}$ above 7.0, with $\mathrm{NH}_{3}$ concentrations increasing as $\mathrm{pH}$ increased. However, DePasquale and Montville (7) concluded that "ammonium bicarbonate inhibits fungi because the bicarbonate anion supplies the alkalinity necessary to establish an antifungal concentration of free ammonia." If that were the case, ammonium sulfate and ammonium bicarbonate would affect $B$. cinerea similarly under alkaline conditions. The following conclusion can be reached based on the presented data: Ammonia gas contributes to the detrimental activity of $\mathrm{NH}_{4} \mathrm{HCO}_{3}$ on $B$. cinerea but is not the sole means for its activity.

Buffering capacity to maintain elevated $\mathrm{pH}$ may be one means for bicarbonate activity, since fungi secrete acid to reduce $\mathrm{pH}$ in their environment. If buffering capacity is high, fungi cannot release enough acid to lower $\mathrm{pH}$ sufficiently for optimal growth. Energy is allocated to acid secretion to obtain a more favorable environment instead of manufacturing components for hyphal extension. Bicarbonates raise internal $\mathrm{pH}$ in conidia of Sphaerotheca pannosa f. sp. rosae and Alternaria brassi- cae (23), probably because $\mathrm{H}^{+}$ions are being secreted to lower external $\mathrm{pH}$. In addition, internal $\mathrm{pH}$ measurements of Fusarium graminearum and Penicillium griseofulvum after treatment with ammonium sulfate or ammonium bicarbonate were elevated (7). Although very important, the buffering capacity of bicarbonates and phosphates is not the main reason either salt inhibits $B$. cinerea colony growth.

Implications. This research achieved the objectives outlined in the introduction. Bicarbonates are effective against $B$. cinerea in vitro colony growth at concentrations as low as $20 \mathrm{mM}$. Moreover, cations contribute little to the activity of the anions, and anions primarily determine effect on $B$. cinerea. Buffering capacity and elevated $\mathrm{pH}$ contribute to bicarbonate efficacy but are not the sole reasons for it; data presented herein support evidence by Marloth (14) "that the bicarbonate ion in itself has the inhibitory power, and this must be ascribed either to its action on the enzymes or enzyme-secreting power of the protoplasm or to a direct toxic influence on the protoplasm itself."

Bicarbonates may have several modes of action against fungi, including buffering an elevated $\mathrm{pH}$ environment and increasing osmotic levels on leaf surfaces, both conditions detrimental to fungal spores. Even though elevated $\mathrm{pH}$, such as that buffered by bicarbonates, can prevent germination, conidial adhesion is dramatically reduced only above $\mathrm{pH} 11.0$ (14). Marloth (14) observed that Penicillium italicum spores treated with hydroxides and carbonates swell, an early step in germination, but the appearance of germ tubes is inhibited; elevated $\mathrm{pH}$ allows spores to remain viable but may interfere with extracellular enzymes required to solubilize and expand cell walls and membranes. Nobecourt (19) demonstrated that sodium bicarbonate inactivates extracellular enzymes from Penicillium species. In addition, bicarbonates may directly interact with membranes to alter normal membrane activities or may disrupt cellular physiology at concentrations well below saturation.

The impetus driving research on bicarbonates as agents to control fungal diseases is the search for chemicals that are safe for humans and compatible with the environment. There is a need for new methods to control $B$. cinerea, because many chemicals will no longer be available for growers of certain crops due to increasing registration costs and full or overflowing risk cups after evaluation under the new Food Quality Protection Act. Since bicarbonates have been proven to be efficacious against fungi in both in vitro and in vivo studies, it is not improbable that they would control gray mold under field conditions. The next paper to be presented by these authors will address bicarbonate control of gray mold 


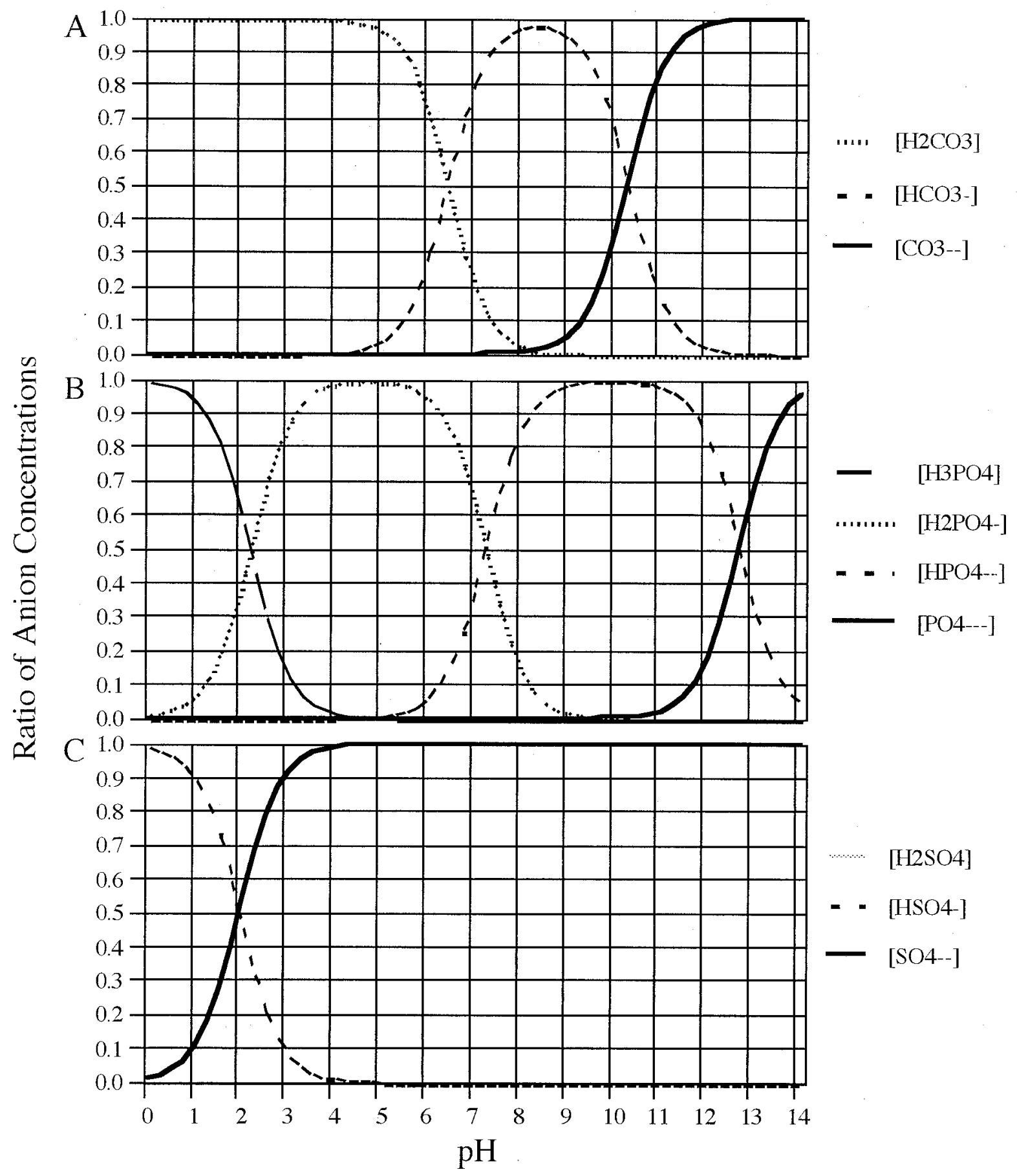

Fig 6. Concentrations of (A) carbonic acid, bicarbonate, and carbonate, (B) phosphoric acid, monobasic phosphate, dibasic phosphate, and tribasic phosphate, and (C) mono- and dibasic sulfate as modified by solution $\mathrm{pH}$, based upon calculations from dissociation constants.

on geraniums. If bicarbonates are demonstrated by in vivo assessments to effectively control gray mold development, they may augment or supplant current fungicide regimens because of their safety and efficacy.

\section{LITERATURE CITED}

1. Anonymous. 1983. The Merck Index. 10th ed. Merck \& Co., Rahway, NJ.

2. Barchietto, T., Saindrenan, P., and Bompeix, G. 1992. Physiological responses of Phytophthora citrophthora to a subinhibitory concentration of phosphonate. Pestic. Biochem. Physiol. 42:151-166.

3. Belanger, R. R., Bowen, P. A., Ehret, D. L., and Menzies, J. G. 1995. Soluble silicon: Its role in crop and disease management of greenhouse crops. Plant Dis. 79:329-336.

4. Carter, M. R., and Locke, J. C. 1994. Botanical oils alone and in combination with fungicide for control of rose black spot. (Abstr.) Phytopathology 84:1077.

5. Clark, S., and Gilein, D. 1991. Horticultural oils. Long Isl. Hortic. News. May 1991, pp. 67.

6. Curran, D. M., and Montville, T. J. 1989. Bicarbonate inhibition of Saccharomyces cerevisiae and Hansenula wingei growth in apple juice. Int. J. Food Microbiol. 8:1-9.

7. DePasquale, D. A., and Montville, T. J. 1990. Mechanism by which ammonium bicarbonate and ammonium sulfate inhibit mycotoxigenic fungi. Appl. Environ. Microbiol. 56:37113717

8. Elad, Y., Yunis, H., and Katan, T. 1992. Multiple fungicide resistance to benzimidazoles, dicarboximides and diethofencarb in field isolates of Botrytis cinerea in Israel. Plant Pathol. 41:41-46.

9. Farr, D. F., Bills, G. F., Chamuris, G. P., and Rossman, A. Y. 1989. Fungi on Plants and Plant Products in the United States. American Phytopathological Society, St. Paul, MN.

10. Homma, Y., Arimoto, Y., and Misato, T. 1981. Studies on the control of plant diseases by sodium bicarbonate formulation. 1. Effects of emulsifiers and surfactants on the protective values of sodium bicarbonate. J. Pestic. Sci. 6:145-153. 
11. Homma, Y., Arimoto, Y., and Misato, T. 1981. Studies on the control of plant diseases by sodium bicarbonate formulation. 2. Effect of sodium bicarbonate on each growth stage of cucumber powdery mildew fungus (Sphaerotheca fuliginea) in its life cycle. J. Pestic. Sci. 6:201-209.

12. Horst, R. K., Kawamoto, S. O., and Porter, L. L. 1992. Effect of sodium bicarbonate and oils on the control of powdery mildew and black spot of roses. Plant Dis. 76:247-251.

13. MacMillan, A. 1954. The entry of ammonia into fungal cells. J. Exp. Bot. 7:113-126.

14. Marloth, R. H. 1931. The influence on hydrogen-ion concentration and of sodium bicarbonate and related substances on Penicillium italicum and $P$. digitatum. Phytopathology 21:169-198.

15. Montville, T. J., and Shih, P.-L. 1991. Inhibition of mycotoxigenic fungi in corn by ammonium and sodium bicarbonate. J. Food Prot. 54:295-297.

16. Moorman, G. W., and Lease, R. J. 1992. Benzimidazole- and dicarboximide-resistant Botrytis cinerea from Pennsylvania greenhouses. Plant Dis. 76:477-480.

17. Mucharromah, E., and Kuc, J. 1991. Oxalate and phosphates induce systemic resistance against diseases caused by fungi, bacteria, and viruses in cucumber. Crop Prot. 10:265-270.
18. Mustonen, H. M. 1992. The efficacy of a range of sulfur dioxide generating pads against Botrytis cinerea infection and on outturn quality of Calmeria table grapes. Aust. J. Exp. Agric. 32:389-393.

19. Nobecourt, P. 1922. Sur le mecanisme de l'action parasitaire du Penicillium glaucum Link et du Mucor stolonifer Ehrb. Compt. Rend. Acad. Sci. (Paris) 174:1720-1722.

20. Palmer, C. L. 1996. In vitro and in vivo effects of bicarbonate on Botrytis cinerea. Ph.D. diss. Cornell University, Ithaca, NY.

21. Palmer, C. L., Horst, R. K., Langhans, R. W., and Israel, H. W. 1993. Effect of bicarbonates on in vitro colony growth of Botrytis cinerea (Abstr.) American Phytopathological Society International Meetings, Montreal, Canada, August 5-9, 1993.

22. Palmer, C. L., Horst, R. K., Langhans, R. W., and Israel, H. W. 1994. Bicarbonates and Botrytis: I. Effects of salts on in vitro colony growth of Botrytis cinerea. (Abstr.) Phytopathology 84:546.

23. Porter, L. L., Urbina-Reyes, R. N., and Horst, R. K. 1992. Bicarbonate inhibition of phytopathogenic fungi in vitro. (Abstr.) Phytopathology 82:247.

24. Punja, Z. K., and Grogan, R. G. 1982. Effects of inorganic salts, carbonate-bicarbonate anions, ammonia, and the modifying influence of
$\mathrm{pH}$ on sclerotial germination of Sclerotium rolfsii. Phytopathology 72:635-639.

25. Punja, Z. K., Grogan, R. G., and Unruh, T. 1982. Chemical control of Sclerotium rolfsi on golf greens in Northern California. Plant Dis. 66:108-111.

26. Reuveni, R., Agapov, V., Reuveni, M., and Raviv, M. 1994. Effects of foliar sprays of phosphates on powdery mildew (Sphaerotheca pannosa) of roses. J. Phytopathol. 142:331-337.

27. Ricker, M. D., and Punja, Z. K. 1991. Influence of fungicide and chemical salt dip treatments on crater rot caused by Rhizoctonia carotae in long-term storage. Plant Dis. 75:470-474.

28. Thompson, D. P. 1989. Fungitoxic activity of essential oil components on food storage fungi. Mycologia 81:151-153.

29. Webb, R. W. 1919. Studies in the physiology of the fungi. X. Germination of the spores of certain fungi in relation to hydrogen ion concentration. Ann. Mo. Bot. Gard. 6:201-222.

30. Ziv, O., and Hagiladi, A. 1993. Controlling powdery mildew in euonymous with polymer coatings and bicarbonate solutions. HortScience 28:124-126.

31. Ziv, O., and Zitter, T. A. 1992. Effects of bicarbonate and film-forming polymers on cucurbit foliar diseases. Plant Dis. 76:513-517. 